\title{
Legal Assistance in the Japanese ODA: The Spark of a New Era
}

\author{
Teilee KUONG*
}

\begin{abstract}
In the 1990s, Japan officially launched its first legal-assistance projects in Asia, becoming the first Asian donor to offer bilateral assistance in the legal field in the post-Cold War profileration of rule-of-law assistance movements. This paper reviews the process of re-shaping the Overseas Development Assistance (ODA) policies in Japan leading up to the adoption of the ODA Charter in 1992 and its subsequent amendments which underlie the changes in importance and relevancy of legal assistance in the overall Japanese foreign-aid policy over the years. The paper also argues that Japan's rule-of-law assistance projects were initially launched with pragmatic considerations but had to be continuously justified for their sustainability with increasingly sophisticated philosophical foundations and practical responses to respond to the changing trends of international co-operation and national political pressures.
\end{abstract}

Keywords: legal assistance, rule of law, ODA, international co-operation, legal reform Vietnam, Cambodia

\section{INTRODUCTION}

Since its first official legal assistance started in Vietnam in the mid-1990s, the Japan International Cooperation Agency (JICA) has been running several legal-assistance programmes to promote legal reforms in some Southeast and Central Asian countries for more than 20 years. Following this initiative, other countries in the region have also launched their own efforts to assist transitional and developing countries to develop their legal infrastructure by providing them with legal models from East Asia. ${ }^{1}$ In terms of scale, scope, and organization, Japan is now an important donor of legal technical assistance in the region. To examine how this Japanese assistance has been delivered, one needs to first understand how

\footnotetext{
* At the time of writing this paper, Teilee Kuong was an associate professor at the Nagoya University Center for Legal Exchange, Japan. This paper would not have been completed without the wonderful working experience in Nagoya and the support of the fellow faculty members and staff at the Graduate School of Law and the Center and many other colleagues working with the Japanese aid community. Correspondence to Teilee Kuong, c/o Nagoya University Center for Asian Legal Exchange Furo-cho, Chikusa-ku, Nagoya, 464-8601, Japan. E-mail address: teileekuong@yahoo.com.

1. The other countries in East Asia that have also joined in these rule-of-law promotion activities are South Korea and, more recently, the People's Republic of China. For some basic information and recent news on the issue, see Shin (2010) and some news articles on China-Cambodia co-operation and assistance in the legal field, such as Jian (2017); Prak (2016).
} 
Japan was drawn into this area and the subsequent context accompanying the development of its legal-reform promotion activities.

The Japanese development aid programme started in the mid-1950s after World War II and became one of the top aid donors in the mid-1980s. ${ }^{2}$ Its focus on Asia has been attributed to different reasons, including economic interests, geo-political considerations, as well as historical and cultural factors. ${ }^{3}$ However, Japan's official engagement in legal-reform promotion abroad has been a relatively recent phenomenon. This needs to be understood in the new post-Cold War context of official development assistance, not only of Japan, but also of the larger community of donors. Reviews of the recent development of Japan's Overseas Development Assistance (ODA) in particular show that the country has reacted to criticisms and adjusted itself to the increasing international rules and norms with regard to provision of ODA abroad, ${ }^{4}$ while, at the same time, it has also been trying to draw attention to the uniqueness of Japan's aid and Japanese potential roles in the region and the world. ${ }^{5}$

This paper will examine the formation of Japan's legal assistance to transitional and developing countries in Asia $^{6}$ by tracing the beginning and development of this phenomenon within the broader context of Japan's changing ODA philosophy and practices. It looks into the paradigm shifts in Japan's foreign-aid policies, particularly in the 1990s, to include legal assistance in its ODA principles and practices. It then reviews Japan's legal-assistance activities on the ground and on the basis of these reviews analyzes the strength and weakness of Japan's legal assistance as part of the country's ODA to Asian neighbours.

\section{JAPANESE LEGAL ASSISTANCE ABROAD: EMERGENCE AND MATURIZATION}

\subsection{Paradigm Shifts in Development Aid}

Until the adoption of the 1992 ODA Guidelines_or “ODA Charter"-Japan's development assistance to foreign countries did not seem to have a clear philosophical statement of objectives or practical guiding principles. ${ }^{7}$ Commentators had frequently attributed Japan's development assistance to the realist desire to pursue narrow national economic interests and to support the US geostrategic and ideological interests during the years of the Cold War. ${ }^{8}$ The 1992 ODA Guidelines and subsequent revisions have opened up new windows for the

2. Seddon (2005), pp. 52-4. More details are given by Kohama, citing the 1956-2004 DAC data that show the total amount of Japanese aid money actually outdid those of Germany, France, and Britain in 1986 and 1987 to become the only rival top runner competing with the US until 2000. It then declined rapidly but retained its second position. See Kohama (2005), pp. 59-65.

3. Sato (2006), pp. 252-4

4. Ibid., pp. 272-89.

5. See Arase (2005), pp. 1-19; Shimomura et al. (1999), pp. 29-30, citing Japan's reaction to the neoclassical economic structural adjustment approach urged by the World Bank and the IMF in the 1980s and Japan's efforts to promote the East Asian development model as an alternative approach to be introduced to some less developed markets.

6. The focus here will be confined to projects run by JICA and officially listed by the Agency as projects in legal cooperation or assistance, thus not including projects run by individual ministries or other agencies, which can be technically categorized as legal assistance but not officially involving or being co-ordinated by JICA.

7. The first ODA Charter was adopted on 30 June 1992.

8. Morrison (2005), p. 25. 
public to take a look at the Japanese explanation of the country's immense spending on its ODA programmes abroad.

Sato Hideo divides the development history of Japan's ODA into six different periods. In his views, the third period (1964-76) was marked by a rapidly expanding ODA. Throughout this period, the total amount of ODA reportedly increased tenfold, from 115,800,000 USD in 1964 to 1,104,900,000 USD in 1976. ${ }^{9}$ JICA was officially established in August 1974 as one ODA executing organization to manage the largest portion of development aid for developing countries. Japan's aid was reportedly "heavily focused on infrastructure" for more than two decades after this third period. ${ }^{10}$ Commenting on the features of Japan's aid philosophy, David Arase states that there existed "an underlying Japanese assumption that development means the growth of industrial production and trade in a state-driven process that can be advanced through the construction of production-related projects and the acquisition of related technologies." 11 Implicated in such comments upon development aid policy is the once dominant criticism of an apparent lack of attention to the development of social and administrative infrastructure. ${ }^{12}$

At the end of the Cold War, peace and democracy gradually loomed largely in all parts of the world. Japan saw the importance of sending a new image of Japan being a country that can contribute to the peace of the world. In terms of international co-operation, this was manifested in at least two major moves inside Japan. First was the adoption of the Law Concerning Cooperation for United Nations Peace-Keeping Operations and Other Operations in $1992^{13}$ and second was the establishment of the ODA Charter. Most commentators on the development of Japanese ODA argued that, until the issuance of this ODA Charter, Japanese ODA had been tied to the economic interests of Japanese business and security arrangements with the US and other allies in the Western camp. Use of ODA as a tool of foreign policy emerged gradually in the 1980s and was consolidated in the 1990s. However, in practice, Japan remained very conservative in its approach to rendering foreign assistance, fearing that it would be accused of interfering in the domestic affairs of the recipient countries, particularly in the context of its relationship with some Asian neighbours. The embarrassment of January 1974, when Prime Minister Tanaka Kakue was received in Indonesia and Thailand by waves of anti-Japan demonstrations, left a durable scar in the Japanese talk about foreign assistance. ${ }^{14}$ Any sensitive issue that might lead to the accusation of interference with internal affairs or return of Japanese imperialism would not be accepted in the foreign-assistance package.

However, in response to the general paradigm shift in development aid to take in political conditionality and emphasis on good governance and other not purely economic issues, Japan, as one of the top donor countries, also felt the need to adjust its aid policy and practice

9. Sato, supra note 3, p. 262.

10. Kevin Morrison made this statement citing the unchanging percentage of Japan's bilateral aid committed for economic infrastructure between 1977-78 and 1997-98, comparing that to the trends of the World Bank and the International Development Association (IDA) during the same period. Morrison, supra note 8, p. 26.

11. Arase, supra note 5, p. 268.

12. Morrison, supra note 8, p. 27. In this context, Morrison however argues that some changes took place in the 1990s to refocus on the "soft" type of aid.

13. For more details about this law, see Yanai (1993), pp. 33-75.

14. Shimomura et al., supra note 5, p. 64. 
to the emerging trend. ${ }^{15}$ The adoption of the 1992 ODA Charter reflected this shift. The Basic Philosophy clearly stated the following points:

The world is now striving to build a society where freedom, human rights, democracy and other values are ensured in peace and prosperity. We must recognize the fact of interdependence among nations of the international community and that stability and the further development of the developing world is indispensable to the peace and prosperity of the entire world. ...

It is an important mission for Japan, as a peace-loving nation, to play a role commensurate with its position in the world to maintain world peace and ensure global prosperity.

Bearing these points in mind, Japan attaches central importance to the support for the self-help efforts of developing countries towards economic take-off. It will therefore implement its ODA to help ensure the efficient and fair distribution of resources and "good governance" in developing countries through developing a wide range of human resources and socioeconomic infrastructure, including domestic systems, and through meeting the basic human needs (BHN), thereby promoting the sound economic development of the recipient countries. In so doing, Japan will work for globally sustainable development while meeting the requirements of environmental conservation. ${ }^{16}$

These paragraphs are self-explanatory of Japan refocusing its foreign-aid policy in response to a world that is "now" striving to build a new order based on some non-economic values. To assist in maintaining this new order, Japan "attaches central importance to the support for the self-help efforts of developing countries" and implements its ODA to help ensure "good governance" in developing countries. According to Shimomura Yasutami and others, Japan's "knowledge-based assistance" projects gradually developed in the context of this adjustment during the late 1980s and early 1990s. ${ }^{17}$ The first significant "knowledgebased assistance" project was executed by JICA in Vietnam in the form of policy advisory services under the "marketization assistance scheme," in which Professor Ishikawa Shigeru and several Japanese scholars participated. ${ }^{18}$ Although this was not yet really the beginning of the legal-assistance project, the groundwork for it was actually formed by this and similar earlier moves.

\subsection{Joining the Club of Rule-of-Law Promoters}

\subsubsection{Official Commencement of Japan's Legal-Assistance Programme}

Reviews of the history and development of Japan's legal-assistance programmes have to start from the discussions on how current legal assistance is understood. In the Japanese context, since the early 1960s, the Ministry of Justice has been working with the United Nations Asia and Far East Institute for the Prevention of Crime and the Treatment of Offenders (UNAFEI) in organizing different regular training programmes for legal and law-enforcement officials from developing Asian and African countries. ${ }^{19}$ These are undoubtedly an important part of the legal-assistance activities. However, they are not the same as current legal-assistance programmes in two ways. First, despite the fact that Japanese legal professionals were

15. Nakagawa (1993), pp. 76-99.

16. Japan's Official Development Assistance Charter adopted by the Cabinet on 30 June 1992.

17. Shimomura et al., supra note 5, p. 30.

18. For more details, see Ishikawa \& Hara (1999).

19. This experience is sometimes referred to as an example of legal assistance that does not necessarily cause any controversy regarding national sovereignty of the recipient country. See e.g. Yamashita (2010), pp. 22-5. 
directly involved in the training, the activities were carried out as Japanese contributions to multilateral efforts to promote legal development in these developing countries. It is not a bilateral programme, clearly reflecting the official position of the donor state in providing such assistance. Second, the current Japanese legal-assistance programme is far more comprehensive and policy-oriented than these past trainings. The UNAFEI experience consisted mainly of the training of human resources and the creation of international co-operation networks. The JICA experience since the 1990s has been assisting the development of policy- and law-making as well as the subsequent legal-implementation capacity of the recipient countries. The two experiences differ from each other in terms of objectives, responsibilities, and impacts.

Current legal-assistance activities implemented by JICA started after the adoption of the 1992 ODA Charter, which can be most conveniently used as a technical reference to the issue of principles and objectives of Japan's foreign development aid policy. The ODA Charter was issued by the Cabinet in 1992, after continuous efforts of the Diet to enact a law to regulate international technical co-operation had failed between 1975 and $1990 .^{20}$ It was later amended into a comprehensive policy document in 2003. The concept of good governance that had been stated in the 1992 Charter was further qualified in 2003 by, inter alia, initiating legal-assistance programmes for the development of recipient countries. ${ }^{21}$

Despite the fact that, at the time of the adoption of the ODA Charter, the concept of "good governance" as a central element in development assistance was drawing increasing attention in the mainstream philosophy of the aid community elsewhere, one may also recall that the early 1990s was the time when Asianization of some universal values took place-most strongly in some leading East and Southeast Asian countries. There were hot debates about an Asian way of human rights and democracy and, for the same reason, a very strong argument for "good governance" in the Confucian cultural context.

Apart from these strategic considerations, there were also some important factors in the Japanese administrative context that did not enable a quicker introduction of legal-assistance projects into Japan's development aid programme. That was because of the relatively strong independence of the bureaucracy, which had a significant voice in setting the routine policymaking of the country. Despite the fact that "good governance" and rule-of-law assistance entered into foreign development aid programmes elsewhere, Japanese aid bureaucrats were quite reluctant in promoting freedom or democratization assistance as the leading feature of Japan's international co-operation. The following sentences extracted by Sawamura from a 1991 ODA report of the Japanese Ministry of Foreign Affairs indicates Japanese foreignaffairs officials' position regarding the question of promoting good governance abroad:

Japan's approach differs considerably from that of the United States, which regards freedom and democracy as universal values and has made the promotion of these ideas a basic component of its aid activities .... As much as possible, Japan strives to avoid the imposition of its own political values or attitudes toward economic development on its aid activities. Instead it has sought to

20. For more discussions about the history of Japan's ODA Guidelines in the second half of the twentieth century, see Chapter 2 in Shimomura et al., supra note 5.

21. The relevant paragraph states: "The most important philosophy of Japan's ODA is to support the self-help efforts of developing countries based on good governance, by extending cooperation for their human resource development, institution building including development of legal systems, and economic and social infrastructure building, which constitute the basis for these countries' development" (Revised ODA Charter adopted on 29 August 2003, s. 2(1)). 
discover, through a process of dialogue based on requests from recipient countries, the best approach to development for each individual country. ${ }^{22}$

It actually took Japan another four years after the adoption of the 1992 ODA Charter to start incorporating legal assistance into the ODA programme for the promotion of good governance in Asia. It was a gradual process, initially led by people outside of the official aid community in Japan in the first place, seeking to change the conservative bureaucratic culture. This gradual process of change started in the early 1990s when Japanese selfdefence forces (SDF) were officially dispatched for the first time to Cambodia. The move was well received as a positive change in the Japanese approach to foreign assistance. It marked an important break from the long-alleged faceless Japanese development assistance policy. Japanese people then discovered that there was something that Japan could contribute to the world of foreign assistance in the field of good governance and the building of peace in a post-conflict society. It was now felt that the SDF, the civilian police, lawyers, university professors, and all Japanese citizens can be part of this "world peace" movement.

Soon after the adoption of the 1992 ODA Charter, JICA supported a "knowledge-based" assistance programme initiated by a group of Japanese economic scholars, led by Professor Ishikawa Shigeru. This group of scholars was requested by the Vietnamese government to help review and develop a new national policy for Vietnam's transition to a market economy in the mid-1990s. This project was acknowledged and appreciated by the very top politburo of the Vietnamese government and the Communist Party. JICA was convinced that it was an advisory service, recognizable as the knowledge-based assistance to promote Vietnamese good governance in her transition towards a market economy. Japan had just a few years earlier convinced the aid community that there was something of an East Asian model to economic development and Japan was a leading example. ${ }^{23}$ This Vietnam project would put the alternative models into real experiments. It was an important time for Japan to move away from the micro-level technical assistance in economic terms and offer her own experience of an Asian model to another country in Asia. "Good governance" promotion in this context was confined to assisting a transitional country in developing its own capacity in setting national economic policy suitable for the market transition and reform that the recipient was aiming at. It was "good governance" assistance from a strictly economic viewpoint, but it nonetheless constituted an important entrance into the realm of legislative assistance.

From the "knowledge-based" assistance as the starting point, foreign aid nonetheless had to be further justified by the objectives it seeks to serve and philosophical principles behind the assistance projects. To emphasize this point, the ODA Charter was later revised in 2003 to recognize the emergence of a "new environment, grappling with a multiplicity of problems such as ... suppression of freedom, human rights and democracy." It included in the basic policies on supporting "self-help efforts" the following commitments: "Japan will give priority to assisting develop oping countries that make active efforts to pursue peace,

22. Sawamura (2004), p. 34.

23. This was particularly evident in Japan's sponsorship for large-scale studies of the East Asian economic development models in search of alternatives to the structural adjustment approach to development assistance practised by major donors in the 1980s. Results of these studies were published in some major works of the 1990s. See e.g. World Bank (1993). 
democratization, and the protection of human rights, as well as structural reform in the economic and social spheres." 24

These basic policies suggest that Japan's claim to be different from the West, as expressed above in the administration's 1991 ODA report, is not as strong as it used to be. Ideas about what is universal and what is not may have converged. Meanwhile, rhetorical claims of the existence of a Japanese way to provide legal assistance might have also served the purpose of mobilizing Japanese ODA for the promotion of the universal values, as some of these values had already been implanted, or Japanized, in the Japanese formal legal and political systems for several decades under the Constitution of 1947.

\subsubsection{The First Legal Assistance Donor Experience in Asia: Setting the Stage}

From a jurist's perspective, enactment or amendment of private laws would be necessary for any national orientation away from the planned economy towards a market economy. Making use of existing individual relations with some Japanese legal scholars, high-level legal officials in Vietnam also approached individual Japanese law professors to explore the possibility of receiving technical advisory services in legislative drafting and amendments. Professor Morishima Akio, the former Dean of the School of Law and then Dean of the Graduate School of International Development of Nagoya University, was consulted by the Vietnamese Ministry of Justice on this issue.

Being a famous specialist in the Civil Code, Professor Morishima enthusiastically responded to the request and tried to convince the Japanese government to commence a legal-assistance project with Vietnam. It actually took the government a few years to finally set up the official project. But Morishima already started organizing his own missions to Vietnam and offered his technical comments to the Vietnamese Ministry of Justice in respect of the drafting of the 1995 Civil Code. ${ }^{25}$ At about the same time, the Cambodian Ministry of Justice also expressed interests in obtaining Japanese help in the drafting of some major laws after the country's transition towards democracy and market economy that had started in 1993.

On the other hand, some Japanese lawyers were getting interested in the transition in Cambodia. Having witnessed in the early 1990s a serious lack of legal infrastructure in the country's transition, they saw a role for Japan to be involved in helping Cambodia rebuild its legal system, particularly in the training of lawyers and reforming of the criminal justice system. Several reasons may account for an improved environment for Japanese engagement in legislative support for Vietnam and Cambodia. First, requests for such assistance came from high-level officials of the potential recipient countries, specifically asking for Japan's assistance in the field of legislative drafting. Second, in line with the adoption of the 1992 ODA Charter, leading jurists in Japan started to lobby strongly for Japan's commitment to legal assistance abroad. Third, eager to promote the East Asian development model and being bound by the past habit of linking ODA strictly to economic development and national interests, the Japanese official aid community saw another way to offer knowledge-based support for the development of an Asian country in transition. They finally agreed to provide legal assistance to "transitional economies" in the field of "civil and commercial laws," focusing in particular on the transition to market economy of these countries in Asia. These factors together marked a

24. Revised ODA Charter adopted on 29 August 2003, s. 2(1).

25. For some details of Morishima's experience in advising the draft 1995 Civil Code, see the keynote speech by Morishima Akio transcribed and printed in Japanese in Research and Training Institute of the Ministry of Justice (2006), pp. 16-21. 
relatively humble departure of Japan to join the good-governance and legal-assistance activities. Whereas almost all good-governance assistance promoters during those days were from developed countries in the West and selling a multiple-item menu of the legal assistance abroad, Japan opted for a narrower concept of good governance and legal assistance within a technical scheme tailored to helping countries to start their marketization process.

\section{STRATEGIES AND LEGITIMACY ${ }^{26}$}

In addition to the bureaucratic inertia and specific nature of Japanese ODA formation mentioned above, some important historical and political contexts in Japan had added to the reluctance in the country's approach of avoiding bolder legal-assistance activities. This section looks into these contexts and briefly explains what controversies arose in terms of pros and cons vis-à-vis Japan's legal-assistance programmes abroad.

With the successful dispatch of SDF to join the UN peace-keeping operation in Cambodia in 1991, Japan officially referred to its constitutional provisions on peace and international co-operation as a suitable contribution to peace outside of Japan. The argument suggested that Japanese pacifism, backed by a strong democratic system and respect for human rights and the principle of rule of law, was a major enabling factor for Japan's economic development for recent decades. Even though this was not disputed by officials in the Japanese aid community, they were not yet ready to consider including these values of Japanese political and legal systems in the technical-assistance package for transitional countries. Instead, the Japanese contribution to peace and development in the Asia-Pacific region was limited to facilitation of the diplomatic process and political dialogues. Shimomura and others found that the first case of Japan's direct assistance in democratization was the holding of a democratization seminar in Tokyo for government officials from Africa and Latin America. Japan had not had earlier experience in this kind of aid. ${ }^{27}$ Some specific projects were only developed afterwards, including the marketization assistance to Vietnam in the mid-1990s and assistance to policy-making in Poland and Uzbekistan. ${ }^{28}$ Subsequently, a programme called "Partnership for Democratic Development" (PDD) started as a synthesis of Japanese aid in the field of law and democracy. The approach to its implementation is reportedly "to assist the self-help efforts" of developing countries seeking democratization. ${ }^{29}$

As said, two major factors might be accountable for the slow re-orientation towards initiating projects in legal and democratization assistance until the 1990s. First was the fact that Japanese development assistance until then had been purely focusing on assistance for economic take-off and development. No JICA officials were recruited from the circle of lawyers or experts in the legal sector. ${ }^{30}$ Therefore, technically, Japanese aid officials might not have sufficient clues about and perhaps were not interested enough in the relevant legal aspects of the global debates about support for good governance in the 1980s and 1990s. Second, given the Japanese sensitivity towards some of her Asian neighbours' concerns

26. More details and analyses on this topic can be found in Nicholson \& Kuong (2014), pp. 141-77.

27. Shimomura et al., supra note 5, pp. 125-6.

28. Ibid.

29. For some information on Japan's democratization assistance, see Ichihara (2013).

30. Only recently have some practising attorneys been recruited as full-time JICA advisers and officials to oversee the good-governance and legal-assistance projects at JICA Headquarters in Japan. Kagawa \& Yuka (2007), p. 82. 
about the possible return of an imperialist Japan, it was feared that any sign of potential interference into the internal affairs of these countries would lead to antagonism and should be avoided in the Japanese foreign-aid practice. In the 1980s and 1990s, it had been a concern of the Japanese aid community that any imprudent involvement in governance issues of the recipient country would lead to suspicions of a political attempt to insert a foreign-political agenda by means of development aid into the recipient country ${ }^{31}$ and thus might be viewed by the recipient country as an imperialist attitude of the donor country and might lead to antiJapan sentiments in the recipient society. Japan just could not afford being labelled in that way in its relationship with its Asian neighbours.

In academic circles, there were two obviously different trends of thought regarding the question of Japan's appropriate approach to legal assistance. On the one hand, it was argued that legal assistance should not be limited to civil-commercial fields only. The door should be open to other fields as well if the need exists. Mere focus on civil-commercial fields is not sufficient from the viewpoint of legal assistance to promote "good governance." As the marketization process develops further, other legal and institutional issues such as reforms of the public administration, and in that connection administrative law reform, may need to be tackled as well. ${ }^{32}$ On the other hand, scholars directly involved in the ongoing JICA projects argued that economic development was the priority issue in many of the transitional countries in Asia. In many of the socialist market economies, they said that talks of foreign assistance in politically sensitive legal fields could end up being seen as an attempt to interfere in the internal political affairs of the country. Assistance in promoting a proper civilcommercial legal infrastructure would enhance respect for private autonomy and property rights. Adoption of rules for private relationships under the Civil Code enables people's access to civil justice and therefore stabilizes people's lives in the society. In the long run, it would also contribute to respect for human rights in a broader sense. ${ }^{33}$

However, the two camps seem to share one common view that Japanese legal assistance started without sufficiently detailed deliberations on its own strategic approach. ${ }^{34}$ It was officially launched and later expanded, based on pragmatic considerations, namely responding to pending specific requests from Japan's Asian neighbours. As Japanese legal assistance started with strong scholarly involvement, discussions about its philosophy and approaches quickly attracted academic attention among the legal scientists. ${ }^{35}$

Notwithstanding these differences, there has been wide consensus that Japan has something unique to contribute to the ongoing legal development of transitional and developing countries in Asia, in particular, thanks to Japan's long history of introducing and tailoring foreign legal models and systems to its domestic needs. The past experience of being a

31. Proponents of Japan's stronger involvement in governance promotion or legal assistance argued that, by the early 1990s, Japanese aid agencies did not believed that legislative assistance could possibly be made a part of technical assistance. In a chapter published in 2004, Osamu Koike argues that "development studies in Japan has so far mainly been led by economic studies, but since the prime theme of development is shifting towards 'good governance,' contributions from the field of political science, public administration, and law will become increasingly in demand." For the former argument, see Yamashita, supra note 19, p. 23, whereas the latter argument can be found in Koike (2004), p. 100.

32. Aikyo (2011), pp. 171-2.

33. Morishima (2000), pp. 130-1.

34. Aikyo (2011), pp. 168-9.

35. Aikyo comments on some relevant issues in Aikyo, supra note 32, pp. 184-9. 
relatively successful recipient of modern legal systems would be a useful reference for contemporary recipients of diverse sources of rule-of-law assistance. Legal assistance based on a post-modernist comparative law approach could be the advantage of a Japanese model of legal assistance.

\section{RECENT REVISION OF THE ODA CHARTER AND NATIONAL INTERESTS IN DEVELOPMENT CO-OPERATION}

On 10 February 2015, the Japanese government adopted new revisions of the ODA Charter by a cabinet decision. The Charter was renamed the "Development Cooperation Charter," reflecting an important rhetoric shift from "assistance" to "co-operation." This 2015 Charter keeps many original features of the 2003 ODA Charter but organizes the contents in a more systematic way, reflecting the increasing maturity in thinking and experience of over 60 years of Japanese ODA history. However, some new features have also been added to reflect Japan's adjustment of its ODA policies to contemporary needs. The revision was considered necessary by the Abe administration to respond to several major political changes in the global and regional contexts. In its connection to the topic of legal assistance, ${ }^{36}$ this section will focus on two new features in this new Charter, namely the emphasis on "national interests" and the replacement of "assistance" with "co-operation." The following subsections will look into these two issues separately.

"National interests" appears three times in the new Charter, as opposed to the 2003 ODA Charter, which made no direct mention of this phrase. The three references all appear in the introductory paragraphs of the document to underlie the fundamental thinking of the Charter and the philosophical basis. The immediate contexts are as follows:

a peaceful stable and prosperous international community is increasingly intertwined with the national interests of Japan. To secure its national interests, it is essential for Japan, as a "Proactive Contributor to Peace" based on the principle of international cooperation, to work together with the international community including developing countries to address global challenges.

In the section on "Philosophy," wherein the "objectives of international cooperation" are mentioned, the phrase emerges for the third time:

Based on this recognition, Japan will promote development cooperation in order to contribute more proactively to the peace, stability and prosperity of the international community. Such cooperation will also lead to ensuring Japan's national interests such as maintaining its peace and security, achieving further prosperity, realizing an international environment that provides stability, transparency and predictability, and maintaining and protecting an international order based on universal values.

Tying ODA to national interests is no longer an implicit policy. ODA in the form of development co-operation in pursuit of national interests of Japan, once going beyond pure rhetoric, may logically be understood to mean more reciprocity in concrete terms and more of a contractual relationship based on prior accepted considerations between sovereign equals. There seems to be an intentional shift, at least in theory now, away from provision of assistance to the establishment of a development partnership, no longer in terms of assistance

36. For some information and analyses, see Wakita (2015), pp. 72-85. 
by the more able to the less able, the more affordable to the less affordable, but co-operation for development as a common goal between equal partners.

In the context of legal assistance, the recipient countries may also begin to muse over the practical implications of this new emphasis on Japan's national interests. The Charter remains very cautious in avoiding any possible misunderstanding by making reference to this politically sensitive phrase in the broad context of common global interests and values. Although this may mean business as usual, given the fact that the previous charters also placed the upholding of common global goals and values as the justifications for legal assistance, the new Charter explicitly gives Japanese government an open space to interpret which of these goals and values serves better Japanese national interests in its contractual relationship with the recipient countries. The newly inserted language also gives sufficient legitimacy for the recipients to openly speak about what they think would constitute Japan's national interests vis-à-vis theirs.

\section{JAPANESE LEGAL ASSISTANCE IN PRACTICE}

As of 2018, JICA has officially listed 11 countries in Asia as the target countries where JICA has implemented "major technical cooperation and trainings in the legal and judicial sector." ${ }^{37}$ The third project after those in Vietnam and Cambodia was launched in Laos in 2003. All projects have apparently been tailored to meet the specific needs and perceived circumstances of each recipient country, with perhaps also Japanese national interests considered, but the basic approach and philosophy of a carefully crafted partnership and collaboration between expert groups remain highly obvious and should be attributable to the first experience with the two major projects initiated with Vietnam and Cambodia. This section will therefore review the first two projects and identify some key lessons that were learned from these earliest experiences and seemingly remain to dominate the JICA's approach to legal assistance today.

\subsection{The Vietnam Project as the Point of Departure}

Soon after Vietnam's Civil Code was adopted in 1995, it was found that the Code fell short of responding to the needs of the evolving marketization. It retained some features of a socialisttype Civil Code, which was not made to regulate solely private legal relations. ${ }^{38}$ Responding to Vietnamese efforts to seek Japanese assistance in amending the Code, JICA officially launched the first comprehensive legal-assistance project in Vietnam and offered that country the Japanese expertise in this area. The project officially started in 1996. It was subsequently developed into new phases in 2000 and 2007.

To reflect the concept of a partnership and to avoid the risk of one-way introduction of a foreign model, the project started with the establishment of a consultation group formed by Japanese scholars and Vietnamese jurists to discuss and exchange views on specific civil

37. These are Vietnam, Cambodia, Laos, China, Uzbekistan, Mongolia, Indonesia, East Timor, Nepal, Myanmar, and Iran. See the list at the end of this paper. For more details, see also JICA's World (2017).

38. Some details are mentioned in keynote speeches made by Hoang The Lien, former Minister of Justice of the Socialist Republic of Vietnam, Professor Morishima Akio, and Professor Nomura Toyohiro, transcribed and printed in Japanese in Hoang (2006), Morishima (2006), and Nomura (2006). 
legal issues to be included in the amendment. ${ }^{39}$ However, as discussions among members of the group went on, the Vietnamese counterpart realized that partial revision would not help. Instead, it needed a complete overhaul of the Code. ${ }^{40}$ So, during the first phase of the assistance, JICA decided to assist in the organization of regular consultations between the Japanese consultation group members and the Vietnamese drafting committee members. The former would offer comments and advise on specific issues consulted by the latter and the Vietnamese Ministry of Justice officials themselves would decide what to incorporate into the new draft Code. Japanese experts were not directly involved in the actual drafting of the Code. The whole consultation and drafting process took three years and the new Civil Code was completed in 2003. The new Code gives official recognition to the principles of "private autonomy" and "freedom of contract." It also introduces a new system of security in transaction that is much like the Japanese one. ${ }^{41}$

In 2002, Vietnam also requested Japanese assistance in the amendment of its civil procedures. For two years, a similar consultation process was organized for scholars and experts in Japanese civil procedure law to offer comments on the new Vietnamese draft Civil Procedure Code. This new Code would replace the 1989 Decree on civil dispute-settlement procedures, the 1992 Decree on economic dispute-settlement procedures and the 1996 Decree on labour dispute-settlement procedures. ${ }^{42}$ The new Code was finally adopted in June 2004 and came into force in January 2005.

\subsection{The Cambodia Project as an Extreme Test of Legal Assistance}

The Cambodia project is for Japanese legal-assistance planners a rather exceptional case. It was generally believed at least at that time that Cambodia was in dire need of professionals in both legislative drafting and legal implementation. To expect Cambodian legal officials or practitioners to draft a comprehensive Civil Code on their own was unrealistic. ${ }^{43}$ But, on the other hand, drafting a Civil Code on their behalf might end up in alleged interference in the legislative sovereignty of the country. The final draft would most likely be considered a foreign imposition without sufficient domestic inputs. One solution was then to organize a joint working process through which Japanese legal knowledge could be transferred and incorporated into the new draft Code. Cambodian experts would be able to contribute to the codification process with their knowledge about Cambodian law and practices and the real situation inside Cambodia. A joint working-group model was developed, through which the drafting process took place rather slowly and in a form of experts' dialogues. ${ }^{44}$ A Japanese working group was set up in Japan to discuss and initiate draft provisions that would then be reviewed by Cambodian working-group members. These representatives from the Ministry

39. Kagawa \& Yuka, supra note 30, pp. 92-3.

40. Ibid., pp. 94-5.

41. Some more details of the substantial similarities and differences between the Japanese and the new Vietnamese codes can be found in Kagawa \& Yuka, supra note 30, pp. 95-7, and Nomura Toyohiro's keynote speech "Main Amendments in the Vietnamese Civil Code," transcribed and printed in Japanese in Research and Training Institute of the Ministry of Justice, supra note 25, pp. 21-6.

42. Kagawa \& Yuka, supra note 30, pp. 85-90. This publication also provides some details on the contents of the advice offered on the draft, and the resulting similarities and differences between Japanese and Vietnamese civil procedures.

43. Homma (2011).

44. Ibid. 
of Justice, legal professionals and officials from other relevant ministries would discuss the draft provisions prepared by the Japanese counterparts and finalize it based on the results of the consultations inside Cambodia. ${ }^{45}$ But asymmetry in legal knowledge and information, particularly with regard to the legal system in a market economy and the Western modern legal concepts, created certain limits to the quality of the dialogues. To mend this technical asymmetry, training and other forms of technical co-operation programmes to promote the quality of these dialogues were developed and implemented side by side with the legislative drafting assistance programme. ${ }^{46}$

This started a move beyond mere provision of legislative drafting assistance. The project also had to focus on capacity-building and human-resources development, at exactly the same time as the commencement of the drafting assistance. Several issues emerged in this shift. First, to ensure effectiveness and consistency between the ongoing legislative drafting assistance and the capacity-building for officials involved in this drafting, it was necessary to ensure that the trainees in these training programmes and the members of the drafting committee had to be the same people. Second, implementation of legislative drafting assistance in combination with intensive training and capacity-building in this way not only requires financial resources and is time-consuming; it also demands a tremendous amount of high-quality translation work in legal concepts and terminology. Securing these latter resources was not an easy task on the part of the assistance provider. The translation work was mainly done by a pool of JapaneseCambodians who had been living in Japan for decades and spoke both Japanese and Khmer fluently. But the translation was also hampered by a lack of Cambodian expertise in the highly sophisticated technicality of the concepts and terminologies used in the provisions of the draft Civil Code. A lot of these concepts and terminologies either had not existed in the Cambodian law or were simply not familiar to Cambodian translators.

To address this problem, a legal terminology working group was formed in Phnom Penh. The group consisted of core members of the Cambodian Working Group and the Japanese coordinator who speaks Khmer and was based in the project office in Phnom Penh. As a result of these deliberate arrangements, the project was featured by a combination of technical assistance and foreign-local partnership. The initial draft articles would be drafted by the Japanese experts based on the results of the consultations among Japanese and Cambodian members at the working-group meetings. The draft was then translated into Khmer by a group of Japanese-Cambodians who were mostly linguistic but not legal experts. When the Khmer version of the draft was translated, it had to be reviewed by the legal terminology working group again for further technical adjustments by Cambodian experts who could not understand Japanese but had participated in the pre-drafting discussions and possessed practical knowledge about Cambodian legal concepts and terminologies used in the field.

This "working group" model has since been considered one important feature of Japan's legal-assistance project to Cambodia. It has been argued that the model not only enabled the assistance provider to receive technical feedback from the local counterparts before the final product was completed, but also enabled the local counterparts to benefit technically from the project by having access to the detailed discussions before the draft was made and/or finalized and to the exclusively technical training that was particularly tailored to the specific

45. Morishima (2003), p. 5.

46. Ibid., p. 7. 
needs of legislative drafters. In addition, seminars and workshops were frequently organized in Cambodia and Japan to enable members of the working groups to discuss details of specific issues encountered during the drafting. These seminars and workshops took place in two forms: technical lectures by Japanese scholars and exchange of information and views between Cambodian and Japanese working-group members.

By the time the drafts of both codes were completed, there were already 51 meetings of the two working groups respectively, 17 workshops on the Civil Code, 13 workshops on the Civil Procedure Code in Cambodia, and seven training sessions in Japan. ${ }^{47}$

Another feature of the Cambodia project was the combination of training and education with the drafting assistance. This was particularly emphasized in the second and the third phases of the project. In the second phase of the project, the Cambodian Royal School for Training of Judges and Prosecutors (RSJP) and the Training School of Lawyers (TSL) were nominated as official counterparts of the project in addition to the Cambodian Ministry of Justice, which had been the sole counterpart institution during the first phase. Japanese judges, prosecutors, and lawyers were dispatched to the RSJP and the TSL to help prepare teaching materials on the new Civil and Civil Procedure Codes. Training seminars were also organized in Japan to train outstanding young Cambodian judges and prosecutors selected from the graduates of the RSJP. A majority of them would later be selected as future core trainers at the RSJP. ${ }^{48}$

As a result of this model of legal assistance, not only were two sophisticated modern codes adopted, but also a number of capable jurists and legal officials trained. Some prominent members of the Cambodian Working Group were later promoted to key positions in the Ministry of Justice and the judiciary and actually became key trainers for younger legal professionals at the RSJP in the subsequent years. ${ }^{49}$ These key persons continue to work with the Japanese project in drafting subordinate laws and regulations necessary for the implementation of some specific provisions of the two codes and in developing the latest curriculum for civil and civil procedure law subjects at the RSJP. ${ }^{50}$

\section{CONCLUDING OBSERVATIONS}

One main objective of legal assistance is to transfer technical knowledge of law and legal systems from one context to another. Japan's rise as an active Asian player in this field has a humble history of little more than 20 years. But, unlike many other legal-assistance providers from Europe or the US, Japanese players have never had full confidence in any single-model legal system. Japan's own experience in legal development was originally featured by combination of different systems and flexible application of different sources of knowledge and technology. It is exactly this capacity to produce new hybrids and to conduct comparative studies that has driven Japan to the pursuit of its new role in Asia. One particularly remarkable feature of the Japanese experience of legal development was the role foreign experts played in legal modernization and the strategic inclusion of foreign elements into the

47. Homma, supra note 43, pp. 36-9.

48. Homma (2010), p. 32.

49. Homma, supra note 43.

50. Regular reports on the details of these training seminars in Japan and development of training in Cambodia can be found in the publication of the Research and Training Institute of Japanese Ministry of Justice ICD News (Special Issue) (2009). For example, see Nishimura (2009), pp. 141-5. 
post-Meiji development of the Japanese legal system. It is therefore natural for Japan to see the relevance of its experience for other countries in Asia seeking a swift transition to the market economy following a diversity of models.

This historical background may suggest at least a partial explanation for the fact that respect for local ownership and partnership of the recipient country was strongly emphasized in the Japanese approach to legal assistance abroad, whereas Japan's wariness about its own historical relationship and its desire to maintain good political ties with Asian neighbours may be among the other reasons. The adoption of the working-group approach in the cases of Vietnam and Cambodia has been an apparent attempt to secure a partnership way of working together. Theoretically, it also enables the recipient country to retain ownership over the process and the final product. Members of the working group representing the interests of the recipient country have the opportunity to give their inputs into the discussions and are well informed in advance of the possible advantages and disadvantages of any proposed model.

The development of the second and third phases of the projects in Vietnam and Cambodia also shows JICA's attention to the issue of implementation of the assistance outputs after the legislative drafting assistance is over. This follow-up assistance has two elements. One is the focus on the necessary human resources and the other is assistance for drafting of subordinate laws and regulations or designing of relevant institutions, such as the establishment of regulations for land registration or, for example, a bailment system in Cambodia.

Apart from short-term training programmes implemented by JICA, assistance in humanresources development for the recipient countries has been conducted in close co-operation with universities in Japan. Government officials from the recipient countries are sent to contracted universities where English programmes in law have been made available to pursue higher levels of comparative law studies.

To strengthen its own capacity to initiate and handle more legal-assistance programmes, JICA has in recent years recruited lawyers or legal specialists to participate in the operation and management of legal-assistance programmes. This has enhanced human resources for the supply side of assistance. It has also strengthened its co-operation with universities in Japan to develop education and training programmes for Japanese law students to develop their knowledge and skills in the field of legal assistance. Hopefully, in the future, this new generation of law graduates will form the core resources to contribute to the work of legal assistance and international legal co-operation with other countries in Asia. ${ }^{51}$

There have been frequent arguments that Japan's legal-assistance activities may transfer something uniquely Japanese to the recipient countries. It is said to be something unique to the East or Asia in contrast to the values of the West. While there may be something uniquely Japanese in the legal-assistance activities offered by Japan, it also is just one of the many experiences of "modernization" or relatively successful development of the "rule of law" in Asia. The objective of a legal-assistance programme is to transfer this experience to the recipient country, enabling it to be in the service of the latter. Rule of law in Japan may be different from that in other developed countries in some aspects, in much the same way as rule of law can be different to certain extent too among those other developed countries.

In any case, Japan will have to design its own way of transferring its experiences and conducting legal-assistance programmes to foreign countries and do so mostly based on

51. For some details, see Aikyo (2010), pp. 18-9. 
pragmatic and technical considerations, while giving careful attention to political and historical relationships with neighbours and the international community.

Legal assistance simply as a borderless transfer of knowledge or exchange of legal information and experience may be a common phenomenon that has always happened. But, for it to happen in a planned and systematic way, international legal co-operation-or assistanceprogrammes as a strategic national or international policy needs to be in place. In recent years, the changing political environment inside and around Japan has demanded the Abe administration to further revise the ODA Charter in 2015. One can see more pragmatic elements in the redefinition of international "co-operation" replacing the term of "assistance."

This paper has only looked into the official programmes initiated and operated by JICA over the last 20 years. Evaluations by the institutions concerned and by third parties have been taking place to review the successes and failures and have provided details on the achievements or impacts of these programmes in different terms. ${ }^{52}$ While there is always the question of when is the most appropriate time for an objective evaluation that may sufficiently and properly reflect the real impacts of the programmes, it is safe to say that definite results may only emerge along the course of continual transition and legal development in the recipient countries.

\section{REFERENCES}

Aikyo, Masanori (2010) "Daigaku ni yoru houseibi shien—Jinzai ikusei to hikaku hougaku no kadai [Legal Assistance by Universities-The Issue of Human Resources Development and Comparative Legal Studies]." 82 Houritsu Jiho [Nihon Hyoronsha] 17-21.

Aikyo, Masanori (2011) Houseibi shien to wa nanika [What is Legal Assistance?], Nagoya: University of Nagoya Press.

Arase, David (2005) Japan's Foreign Aid-Old Continuities and New Directions, London: Routledge. Hoang, The Lien (2006) "Cooperation between Vietnam and Japan in the Process of Codifying the 2005 Vietnamese Civil Code." Keynote speech (translated into Japanese), transcribed and printed in 27 ICD News-Law for Development 11-16.

Homma, Yoshiko (2010) "Hou Ritsu Kiso go no kadai [Issues after the Legal Drafting]." 82 Houritsu Jiho [Nihon Hyoronsha] 30-3.

Homma, Yoshiko (2011) "Kokusai shiho shien ni okeru kenkyusha/jitsumuka no yakuwari-kamboja de no jissenrei [Roles of Researchers and Practitioners in International Legal Assistance-The Practical Case of Cambodia]." 62 Jiyu to Seigi [Freedom and Justice] 36-9.

Ichihara, Maiko (2013) Understanding Japan's Democracy Assistance, Washington, DC: Carnegie Endowment for International Peace, Democracy and Rule of Law.

Ishikawa, Shigeru, \& Yonosuke Hara (1999) Vietnam no shijo keizai ka [Vietnam's Marketization], Tokyo: Toyo Keizai Shinposha.

Jian, Wenzhi (2017) "Chinese PG Cao Jianming Holds Talks with Cambodian PG Chea Leng and MoJ Ang Vong Vathana," Procuratorial Daily, 22 November, http://www.ca-pgc.org/ywb/ln/201711/ t20171122_2106004.shtml (accessed 25 May 2018).

JICA's World (2017) "Rule of Law for Sustainable Development and Access to Justice for All." 9 JICA's World 1-16.

Kagawa, Kozo, \& Kaneko Yuka (2007) Housebi shien ron-Seido Kouchiku no kokusai kyoryoku nyumon [Theories of Legal Assistance-Introduction to the International Cooperation in Institution Building], Kyoto: Minerva Shobo.

52. Among many recent evaluations, one led by the Mitsubishi Research Institute, Inc. was completed in February 2015, seconded by the Japanese Ministry of Foreign Affairs in which the author was also involved. The report is available online. See Mitsubishi Research Institute, Inc. (2015). 
Kohama, Hirohisa (2005) Nihon no kokusai kouken [Japan's Role for the World Peace and Prosperity], Tokyo: Keiso Shobo.

Koike, Osamu (2004) 'New Trends of Development Assistance-'Poverty Reduction' and Governance Reform," in M. Toshitaka et al., eds., Kaihatsu Kyoryoku no hou to seiji-kokusai kyoryoku kenkyu nyumon [The Law and Politics of Development Cooperation-Introduction to International Cooperation Studies], Tokyo: Japan International Cooperation Publishing.

Mitsubishi Research Institute, Inc. (2015) "Evaluation of Cooperation for Legal and Judicial Reform," https://www.mofa.go.jp/policy/oda/evaluation/FY2014/pdfs/legal.pdf (accessed 4 June 2018).

Morishima, Akio (2000) "Legal Assistance and Japanese Legal Studies." 62 Comparative Legal Studies $120-36$.

Morishima, Akio (2003) "Engaging in the Cambodian Civil Code Drafting Assistance Project." 11 ICD News (Special Issue)_Law for Development 4-8.

Morishima, Akio (2006) "Amendment of the Vietnamese Civil Code and Japan's Legal Assistance." Keynote speech transcribed and printed in 27 ICD News-Law for Development 16-21.

Morrison, Kevin (2005) “The World Bank, Japan and Aid Effectiveness," in D. Arase, ed., Japan's Foreign Aid_-Old Continuities and New Directions, London: Routledge, 23-40.

Nakagawa, Junji (1993) "Legal Problems of Japan's ODA Guidelines-Aid and Democracy, Human Rights and Peace." 36 The Japanese Annual of International Law 76-99.

Nicholson, Pip, \& Teilee Kuong (2014) "Japanese Legal Assistance: An East Asian Model of Legal Assistance and Rule of Law?" 6 Hague Journal on the Rule of Law 141-77.

Nishimura, Emiko (2009) "Cambodian Legal Technical Assistance Training in Fiscal Year 2009." 41 IDC News (Special Issue) Law and Development 141-5.

Nomura, Toyohiro (2006) "Main Amendments in the Vietnamese Civil Code." Keynote speech transcribed and printed in 27 ICD News-Law for Development 21-6.

Prak, Chan Thul (2016) "China Agrees to Help Cambodia Overhaul Its Criticized Judiciary," 28 September 2016, https://www.reuters.com/article/us-china-cambodia/china-agrees-to-help-cambodiaoverhaul-its-criticized-judiciary-idUSKCN11Y17H (accessed 4 June 2018).

Research and Training Institute of the Ministry of Justice (2006) 27 ICD News-Law for Development, International Cooperation Department, Ministry of Justice, Japan, 1-150.

Sato, Hideo (2006) Shin ODA no sekai-gurobaruka jidai no "ninken no anzen hosho" gud gabananseron to nihon no gaiko senryaku wo kangaeru [The World of New ODA-Considering Theories of Good Governance, "Human Security" in the Era of Globalization and Japan's Diplomatic Strategies], Tokyo: Aoyamasha.

Sawamura, Nobuhide (2004) "Japan's Philosophy of Self-Help Efforts in International Development Cooperation: Does It Work in Africa?" 7 Journal of International Cooperation in Education 27-40.

Seddon, David (2005) "Japanese and British Overseas Aid Compared," in D. Arase, ed., Japan's Foreign Aid -Old Continuities and New Directions, London: Routledge, 41-80.

Shimomura, Yasutami, Junji Nakagawa, \& Saito Jun (1999) ODA taiko no seiji keizai gaku-Unyo to enjo rinen [The Political Economy of the ODA Guidelines-Operations and the Philosophy of Aid], Tokyo: Yuhikaku.

Shin, Seung Ho (2010) "Legal Assistance \& Cooperation of Ministry of Justice" Presented at the First UNCITRAL Regional Workshop in Asia hosted by Korea University Law School and Korean Ministry of Justice, 23-24 November 2010.

Wakita, Yuichi (2015) "The Decision Regarding the Way of Japanese Government's Development Assistance under the Development Cooperation Charter-How Does the ODA Special Committee View the New Charter?" 368 Rippo to Chousa 72-85.

World Bank (1993) The East Asian Miracle: Economic Growth and Public Policy, New York: Oxford University Press.

Yamashita, Terutoshi (2010) "Houseibi shien ga motarasu mono [Derivatives of Legal Assistance]." 82 Houritsu Jiho 22-5.

Yanai, Shunji (1993) "Law Concerning Cooperation for United Nations Peace-Keeping Operations and Other Operations-The Japanese PKO Experience.” 36 The Japanese Annual of International Law $33-75$. 